\title{
POVERTY AND ITS ERADICATION IN INDONESIA: A CASE OF THE IMPLEMENTATION OF VILLAGE FUND PROGRAM IN GORONTALO REGENCY
}

\author{
Roni Mohammad $^{1 *}$, Ferlin Anwar ${ }^{2}$ \\ ${ }^{1 *}$ Department of Economics, State Islamic University of Sultan Amai Gorontalo, Indonesia, ${ }^{2}$ Department of Philosophy, \\ State Islamic University of Sultan Amai Gorontalo, Indonesia. \\ Email: "obiclimber@gmail.com
}

Article History: Received on $21^{\text {st }}$ January 2020, Revised on $10^{\text {th }}$ February 2020, Published on $19^{\text {th }}$ February 2020

\begin{abstract}
Purpose: This study analyses the implementation of the village fund program in poverty reduction related to the program approach, the problems that arise, the implementation of social principles, and its impact on the poor.

Methodology: This study used a qualitative approach, in which the study was naturalistic, and the researchers conduct their research in as natural a condition as possible - the researchers in determining research informants using snowball techniques. The snowball technique allows more informants according to data requirements. The researchers interviewed the key informants and then asked them to mention other informants who made it possible to find out the topic being discussed. Some of the techniques used in data collection were observation, in-depth interviews, focused group discussions, and document studies. Researchers analyzed data by presenting data in the form of data sorting, categorizing data, and grouping data according to the needs of the analysis.
\end{abstract}

Findings: The implementation of the village fund program applies a community approach. This approach encourages the implementation of village funds to apply the principles of accountability, transparency, participation, democracy, and others. The community approach requires the participation of villagers at each stage of the program's implementation, since the planning, implementation, supervision, and preservation of development results. Nevertheless, the implementation of the village fund program was inseparable from several problems. Problems that occur found both at the local government level, advisory assistants, and the community itself. The implementation of the village fund program has more impact on the community, especially poor households.

Implications: The results of this study provide academic contributions to improve the implementation of poverty reduction in general and the implementation of the village fund program in particular.

Novelty: The implementation of the village fund program encourages the participation of village communities in the development of their villages. The involvement of the village community enables development to be carried out in an accountable, transparent, democratic, sustainable manner, and so forth. This approach enables the development to be carried out on target, and poor household communities feel its benefits.

Keywords: Poverty, Poor Household, Village Fund Program, Empowerment, Poverty Eradication, Community Approach.

\section{INTRODUCTION}

Poverty is a social fact whose existence is real, especially in developing countries (Ahluwalia et al., 1979). Indonesia is no exception. According to the Central Bureau of Statistics, the number of poor people on a national scale reached 25.95 million people or 9.82 percent of the total population. Of this number, it turns out that the largest poor population is in the countryside, which is 15.81 million people compared to the urban poor population of 10.14 million people. Meanwhile, locally the percentage of poor people of Gorontalo Province in September 2017 was 17.14 percent (Central Bureau of Statistics, 2018).

The issue of poverty had been the focus of government attention for a long time, especially the new order until the current reform era. In the new order era, for example, the government launched the President Instruction Program for the Underdeveloped Villages, which was administered by the Ministry of Home Affairs. The World Bank-funded program was more focused on building infrastructure supporting underdeveloped villages to cope with the availability of infrastructures such as roads, bridges, toilets, and clean water facilities. Still under the Ministry of Home Affairs, particularly the General Directorate of Village Community Empowerment, the government launched the Urban Ecosystem and Social Dynamics Program (UESDP), a savings and loan program that facilitates business capital loans for the poor. Other ministries, such as the Social Ministry, also did not miss the idea of creating community-oriented programs. For example, the poor welfare program and the independent young family program, also, a program to increase the role of women. There were also programs specifically aimed at people with disabilities driven by the Social Ministry.

Some paradigmatic mistakes in poverty alleviation, in which an analysis that should bring up significant variables to alleviate poverty are insignificant variables included, then strategies to be taken to overcome poverty should not only prioritize economic aspects but also pay attention to another dimension. In order to improve capabilities and encourage productivity, the strategy chosen is to increase the necessary abilities of the poor to increase income, involving the poor in the whole process of poverty reduction (Prawoto, 2009). Programs that focus on the assistance of the poor continue into 
the current reform era. The Presidential Instruction Program for Underdeveloped Villages in the new order era was adopted as the Accelerated Development Program for Disadvantaged Regions at the beginning of the reform era. A few moments later, the Accelerated Development Program for the Disadvantaged Regions was further expanded to become a District Development Program aimed at not only building rural facilities and infrastructure but, at the same time, improving the economy through savings and loans for productive economic businesses. Specifically, for urban areas, the government launched the Urban Poverty Reduction Program. These two poverty reduction programs then metamorphosed into a National Program for Community Empowerment, namely the National Program for Empowerment of Rural Independent Communities in rural areas, while for urban areas, it was called the National Program for Empowerment of Urban Independent Communities.

Along with the issuance of Law No. 6 of 2014 concerning villages, the National Program for Empowerment of Rural Independent Communities was then continued by the village fund program. Researchers have conducted academic studies relating to the implementation of the village fund program. Research conducted by Sari and Abdullah (2017) concluded that the variable ability of village funds and allocation of village funds in explaining village poverty is $99 \%$. This finding is in line with Atmojo et al. (2017), who concluded that the use of village fund allocations was useful in developing economic potential. Research conducted by Meutia and Liliana (2017) found that the general priority policy of village funds was used to meet basic needs, potential local economic development, and construction of village facilities and infrastructure. Mustanir and Darmiah (2016) concluded that the implementation of village funds, both in terms of implementation, community participation, and village development, has been running in a suitable category. Hasniati et al. (2017) explained that there had been an increase in public interest in participating in the implementation of the village fund program. The village community hopes that the village fund program can be directed to community empowerment programs that are directly related to productive community efforts such as improving the skills of artisans so that they can improve their family's economic standard of living. Riyanto and Junaedi (2017) concluded that the use of village funds in underdeveloped villages is following applicable regulations with priority on infrastructure development and community empowerment. The use of village funds has positive implications for the social, economic, and ecological resilience of the village.

This study filled the void of previous research by conducting a study of the implementation of the village fund program in Gorontalo Regency. The focus of this study was the approach and problems in implementing the village funding program, the application of social principles, and its impact on the poor.

\section{REVIEW OF LITERATURE}

\section{Definition of Poverty}

The World Bank introduces the definition of poverty as "an inability to reach a minimum standard of living" (World Bank, 1990). The National Development Planning Agency defines poverty as a condition where a person or group of people is unable to fulfill their fundamental rights to maintain and develop a dignified life (National Development Planning Agency, 2006). These fundamental rights include (1) fulfillment of food needs; (2) health, education, employment, housing, clean water, land, natural resources, and the environment; (3) a sense of security from the treatment or threat of violence; (4) the right to participate in socio-political life. Meanwhile, the National Family Planning Coordinating Board defines poverty as a condition in which a person is unable to maintain himself with the standard of living he has and is also unable to use his energy, mental and physical to meet his needs (National Family Planning Coordinating Board, 2013). The Central Bureau of Statistics defines poverty as the inability to meet minimum standards of basic needs that include food and non-food needs. Poverty is a condition where a person can only meet his food needs of less than 2,100 calories per capita per day (Central Bureau of Statistics, 1999).

Understanding poverty that is currently popularly used as a study of development is poverty that is often found in developing countries and third world countries. The problem of community poverty in these countries is not just a form of income inability but has expanded to form socially and politically powerless (Suryawati, 2004). Correspondingly, Cahyat $\underline{(2004)}$ states that in the late 20th century, a new understanding of poverty emerged, namely that poverty also included dimensions of vulnerability, powerlessness, and inability to express aspirations. So, poverty is pluralistic or multidimensional.

Based on Law No. 24 of 2004, poverty is a socioeconomic condition of a person or group of people whose fundamental rights are not fulfilled to maintain and develop a dignified life. Basic needs that are the right of a person or group of people include the needs of food, health, education, employment, housing, clean water, land, natural resources, the environment, a sense of security from the treatment or threat of acts of violence, and the right to participate in organizing social life and politics.

\section{Causes of Poverty}

Suryawati (2005) divides four forms of poverty, namely: (1) absolute poverty: if the income is below the poverty line or not enough to meet the food, clothing, health, housing, and education needed to be able to live and work; (2) relative poverty: poor conditions due to the influence of development policies that have not yet reached the entire community, causing inequality in income; (3) cultural poverty: refers to the problem of the attitude of a person or community caused 
by cultural factors, such as would not like to try to improve the level of life, laziness, wasteful, not creative despite outside assistance; (4) structural poverty: a situation of poverty caused by low access to resources that occur in a sociocultural and socio-political system that does not support poverty alleviation, but often causes poverty to flourish.

Todaro and Smith (2006) explain that poverty that occurs in developing countries is caused by the interaction of the following six characteristics: a). The level of national income in developing countries is relatively low, and the rate of economic growth is relatively slow. b). Third world countries' per capita income is also still low, and growth is prolonged, there are even some that have stagnated. c). The distribution of income is unequal or uneven. d). The majority of the population in Third World countries must live under absolute poverty. e). Health facilities and services are inadequate and very limited, malnutrition and many epidemics so that infant mortality rates in Third World countries are ten times higher than those in developed countries. f). Educational facilities in most developing countries and the contents of the curriculum are still relatively irrelevant or inadequate.

Cox (2004) explains the causes of poverty, namely: (1) Poverty caused by globalization in the form of the dominance of developed countries over developing countries; (2) Poverty related to development in the form of low participation in development and marginalization of the development process; (3) Social poverty experienced by women, children and minority groups due to their powerlessness; and (4) Poverty due to external factors such as conflict, natural disasters, environmental damage, and high population.

\section{Indicator of Poverty}

Several poverty indicators have been applied in Indonesia today, including the size of the Central Bureau of Statistics, the National Family Planning Coordinating Board, and the United Nations Development Program. The poverty indicator developed by the National Family Planning Coordinating Board uses microdata from the registration of underprivileged and prosperous families I. In this indicator, a family is called poor if: (i) it cannot carry out routine obligations in its religion; (ii) cannot eat twice a day; (iii) not having other clothes to work or go to school and do other activities; (iv) living in a house where most of the rooms are dirt-floored; (v) cannot pay the cost of health facilities. The condition of the so-called poor people can be known based on the ability of income to meet living standards (Nugroho, 1995).

According to the Central Bureau of Statistics (2004), the poverty level is based on the amount of rupiah consumption in the form of food which is 2,100 calories per person per day (from 52 types of commodities that are considered to represent the consumption patterns of the population in the lower layers), and non-food consumption (from 45 types of food commodities according to national agreements and are not distinguished between rural and urban areas). This 2,100 calorie adequacy standard applies to all ages, genders, levels of physical activity, body weight, and physiological status estimates of population size, and this measure is often referred to as the poverty line. People who have a poverty line below are declared poor.

Sajogjo and Pudjiwati (2002) measure poverty levels based on the amount of rupiah household expenditure, which is equated with the number of kilograms of rice consumption per person per year and divided by rural and urban areas. Rural areas: a). Poor, if the family expenditure is less than 320 kilograms of the exchange rate of rice per person per year. b). Very poor, if family expenses are less than 240 kilograms of the exchange rate of rice per person per year. c). The poorest if the family expenditure is less than 180 kilograms, the exchange rate of rice per person per year. Urban area: a). Poor, if the family expenditure is less than 480 kilograms, the exchange rate of rice per person per year. b). Very poor, if family expenses are less than 380 kilograms of exchange rates for rice per person per year. c). The poorest if family expenses are less than 270 kilograms the exchange rate of rice per person per year.

The World Bank (2000) measures the poverty line based on a person's income, and if income is less than the US \$ one per day, then it is said to be poor. The National Family Planning Coordinating Board measures poverty based on two criteria, namely: a). Criteria for Pre-prosperous Families, namely families, cannot practice religion properly, eat a minimum of two meals a day, buy more than one set of clothes per person per year, house floors with a minimum of $80 \%$, and seek treatment at the health center when sick. b). Criteria for a Prosperous Family one, that is, a family that is not able to carry out religious orders properly, at least once per week to eat meat/eggs/fish, buy clothes one set per year, the average floor area of a house of 8 square meters per family member, no there are families aged ten years to sixty years who are illiterate, all children aged five to fifteen years attend school, one of the family members has a regular or regular income, and no one is sick in three months.

\section{Empowerment as a Way of Poverty Eradication}

Mardikanto and Soebiato (2015) explained that community empowerment is an effort made by the community, with or without outside support, to improve their lives based on their power, through efforts to optimize power and increase their bargaining position. In other words, community empowerment is an effort to enable and make people independent. Anwas (2013) states that empowerment is a process to provide power to the weak and reduce power to those who are too powerful so that there is a balance. The definition of empowerment emphasizes the aspects of delegating power, giving authority or transferring power to individuals or communities so that they can regulate themselves and their environment following their desires, potential, and abilities. 
Empowerment is a process and a goal. As a process, empowerment is a series of activities to strengthen the power or empowerment of weak groups. As a goal, empowerment refers to the circumstances or outcomes to be achieved by a social change (Suharto, 2010). Empowerment is a development concept that has the meaning of development, independence, self-empowerment, and strengthening the bargaining position of the lower classes of society against forces in all fields and sectors of life. Besides, empowerment also means to protect and defend by siding with the weak, to prevent unbalanced competition and exploitation of the weak (Prijono \& Pranarka, 1996). Community empowerment is one of the principles of development that centered on the people, with the empowerment of the community in carrying out the process of analyzing existing problems and opportunities and finding a way out according to their resources. The existence of community empowerment, the community will make decisions and plans and then implement and evaluate the activities they do. The results of empowerment are the development of human resources, increased knowledge, skills, and reduced resources from outside parties (Sulistyati et al., 2011). Empowerment is freeing someone from rigid control and giving people the freedom to take responsibility for their ideas, decisions, and actions (Wasistiono, 1998).

Anwas (2013) emphasizes that through empowerment, people gain enough skills, knowledge, and power to influence their lives and the lives of others they care. Obie et al. (2019) suggested several strategies that could be undertaken to empower the poor, namely: 1) conducting critical awareness, 2) strengthening capacity through training, both on the job training and in-service training, 3) comparative entrepreneurial studies, 4) access to information, and 5) access to capital. Adam et al. (2019), in their research related to the empowerment of workers in a brick factory, explained that empowerment could be pursued by three events, namely strengthening capacity, forming institutional organizations, and opening access to production capital. Correspondingly, Rostitawati et al. (2019) in their research on the coast of Limboto lake stated that to empower the poor, it is necessary to do the following things, 1) increase knowledge and skills, 2) increase utilization of local resources, 3) open access to domestic and foreign markets, 4) development of opportunities for alternative economic activities, and 5) formation of local organizations.

\section{RESEARCH METHODS}

The researchers used a qualitative approach in which the study was naturalistic, and the researchers conducted their research in as natural a condition as possible. With a qualitative approach, researchers describe and analyze phenomena, events, social activities, attitudes, perceptions, and individually or in groups related to the implementation of the village fund program. In this case, as the nature of qualitative research, researchers act as instruments as well as data collectors. Researchers in determining research informants used the snowball technique. The snowball technique allows more and more informants according to data requirements. The researchers interviewed the key informants and then asked them to mention other informants who made it possible to find out the topic being discussed. Some of the techniques used in data collection are observation, in-depth interviews, focused group discussions, and document studies. The researchers interviewed village heads, community leaders, beneficiaries, as well as village fund consultants, both experts at the district level, village facilitators, and village local assistants.

Researchers in carrying out observations refer to the following steps. a). make a list of the domains that have been tentatively chosen for observation. b). write basic questions related to these domains to be submitted as a guide for observation. c). identify the places of observation that will provide the best opportunity for conducting focused observations, at which time the researcher will ask basic questions. d). identify activities when the researchers participate in making observations as natural as possible. e). carry out observations and take field notes according to known procedures.

The researchers in this study applied a semi-structured interview. The purpose of a semi-structured interview is to find problems more openly, where the interviewee is asked for their opinions or ideas. Researchers also carry out focused group discussion, which is digging into the topic of the problem in more depth to get more precise information because it allows the focused group discussion participants to check the information conveyed to each other. Meanwhile, researchers, through the study of documents, study the transcripts obtained from existing documents.

Researchers analyzed data by sorting, categorizing, and grouping data according to the needs of the analysis. Sorting the data is done by completing and transforming the raw data written in the field notes so that it becomes a systematic report, and supplementing the information collected with other supporting sources. In analyzing the data, the researchers used the inductive method, where the facts are explained first, then formulated into a conclusion or generalization.

\section{RESULTS AND DISCUSSION}

\section{Village Fund Program Approach in Poverty Eradication}

The poverty eradication program analyzed in this study is the village fund program. The village fund program is the most extensive poverty eradication program currently that reaches all villages in the territory of Indonesia. If seen from its history, the village fund is a change from the previous poverty reduction program, namely the District Development Program and the National Program for Empowering Rural Independent Communities.

The implementation of the village fund is mandated by Law No. 6 of 2014 concerning villages and its derivative regulations, namely Government Regulation No. 47/2015 concerning Amendment to Government Regulation No. 43/2014 Regarding Regulations for the Implementation of Law No. 6/2014, and Government Regulation No. 8/2016 
about the Second Amendment to Government Regulation 60/2014 concerning Village Funds sourced from the State Budget.

The village fund is sourced from the State Revenue and Expenditure Budget allocated for the village, which is transferred through the regency/city Regional Revenue and Expenditure Budget and prioritized for the implementation of development and empowerment of rural communities. The purpose of the village fund is 1) improving public services in the rural areas, 2) eradicating poverty, 3) promoting the village economy, 4) addressing development disparities between villages, and 5) Strengthening rural communities as the subject of development (Ministry of Finance, 2017).

The implementation of the village fund program focuses more on the rural infrastructure program, which in its implementation, uses a community approach. Chapter III Article 4 of Minister of Village Regulation No. 19 of 2017 concerning determination of priority of the use of village funds in 2018 states that 1) priority of the use of village funds to finance the implementation of programs and activities in the field of rural development and empowerment of rural communities; 2) Priority in the use of village funds is prioritized to finance the implementation of cross-cutting programs and activities; 3 ) Programs and activities, as referred to in paragraph (2), including the activities of superior products in rural areas, rural-owned enterprises or shared rural-owned businesses, reservoir, and rural sports facilities under village authority.

The village fund program in reducing rural poverty focuses on solving community-based rural development problems, where the main priority considers the urgency factor for rural communities. It encourages the implementation of the village fund program, which requires the participation of rural communities to be actively involved in the implementation of the program, from the planning, implementation, monitoring, and preservation of development results. Since the initial planning of the activity program, the rural community was fully involved to ensure that the program implemented was not misplaced. Departing from a philosophy that the rural community themselves are aware of all the problems and potential that exists in their village, then the involvement of the rural community in all stages of the activity becomes absolute. In its implementation, each stage of the village fund program activities is accompanied by a consultant, in this case, the village assistant and the local village assistant.

The rural communities in the program planning stage were involved in proposing activities through discussion forums at the village level. Villagers who participate in meetings at the village level are entitled to submit as many activities proposals as they deem urgent to have, have local potential, and are sustainable. Even so, the proposed program that gets priority is a program that has a profound impact on rural communities. It is called the community approach because village fund assistance is not addressed to individuals but rural communities. The higher the impact, the proposed program the more likely it is to become a priority to be implemented. The involvement of rural communities can also be seen in the implementation of programs funded by village funds. In this case, through the village deliberations forum, an Activity Implementation Team was formed whose management was chosen by the rural community, from the rural community, and for the rural community. This team is in charge of implementing the program that has been mutually agreed upon. Besides that, in order to maintain the quality of work, a supervisory team from the rural community was formed in its implementation. Meanwhile, to promote the sustainability of development results, a team of conservationists was formed by, from and for the rural community.

\section{Problems in the Implementation of Village Fund Program}

The results showed several problems in implementing the village fund program. These problems can be classified into the following levels: 1) the level of local government, both regency, district, and village levels; 2) the level of assistant consultant, both at the level of regency consultant, village assistant and village local assistant; and 3) the level of the community itself.

The main problem in the implementation of village funds at the local government level is the slow disbursement of sharing funds. The implementation of the village fund requires the commitment of the local government in the form of providing a funding share of $20 \%$ of the total village fund allocation in the area. Disbursement of funds sharing $20 \%$ of local government treasury to the public is a prerequisite for disbursing the allocation of $80 \%$ of central funds whose disbursement process is through the State Treasury Service Office. The delay in disbursement of regional government sharing funds often impedes the progress of the implementation of the village fund. Another problem that often occurs is the intervention from the district government to the village, in the form of making a Budget and Cost Plan in the regency, and the village government must spend a certain amount of money in place of the cost of making it. This practice is very contrary to the participatory principle, where the preparation of the Budget and Cost Plan is carried out by a planning team that is formed in a participatory manner by the community in the village. Intervention problems sometimes also come from the village head, where the implementation of activities should be carried out by the Activity Implementation Team formed in the deliberation forum, often taken over by the village head. As a result, the Activity Implementation Team is only in the name of the paper, but the fact is that the village head is carrying out the existing activities.

The problems in the implementation of the village fund can also occur at the consultant level, both district consultants, village assistants, and village local assistants. Problems at this level are often consultants directly involved in job auctions by utilizing their position to get certain benefits. In conducting the auction, the consultant cooperates with individual auction participant companies with the lure of fees as compensation. Moreover, field data was also found where the 
consultant worked closely with the Activity Implementation Team with the lure of distributing a certain amount of money. Problems also arise when consultants take advantage of their position as consultants for village funds to gain political benefits by utilizing the poor recipients of the village fund program. Problems also often occur in the Activity Implementation Team, whereas the activity implementers often take advantage of opportunities to gain certain benefits by reducing the quality of work.

Another critical problem that occurs in the implementation of the village fund is related to communication between stakeholders where communication often experiences obstacles. Adam et al. (2019), in their research related to interstakeholder communication in the implementation of the village fund program, explained that communication barriers in the implementation of village fund programs could occur from top-down, bottom-up, horizontal, and diagonal communication. There are various types of communication obstacles that occur in the implementation of village funds, namely: personal barriers, cultural barriers, physical barriers, and environmental barriers.

\section{Implementation of Community Principles in the Implementation of Poverty Eradication through the Village Fund Program}

An absolute requirement in the implementation of various poverty reduction programs, including village funds, is the application of the principles of accountability, transparency, participation, democracy, deliberation, self-sacrifice, and so forth. Law No. 6 of 2014 concerning Villages is a turning point in the paradigm shift in village governance, in which villages are given the authority to regulate and manage government affairs, the interests of local communities based on community initiatives, rights of origin, customs, and social and cultural values of rural communities. In regulating various activities in the village, including the implementation of the village fund based on the 13 principles as follows (Ministry of Finance, 2017): 1) Recognition, namely recognition of original rights; 2) Togetherness, which is the spirit to play an active role and work together with the principle of mutual respect between institutions at the village level and elements of the rural community in developing villages; 3). Subsidiarity, namely the determination of local scale authority and decision making locally for the benefit of the rural community; 4) Diversity, namely the recognition and respect for the value system that applies in the rural community, but by continuing to heed the shared value system in the life of the nation and state; 5) Mutual cooperation, which is the habit of helping one another to build a village; 6) Family, which is the custom of villagers as part of a large family unit in the rural community; 7) Deliberation, which is a decision making process that concerns the interests of the rural community through discussions with various interested parties; 8) Democracy, namely the system of organizing rural communities in a system of government carried out or with the consent of the rural community and the dignity of human dignity as a creature of God the Almighty is recognized, arranged, and guaranteed; 9) Independence, which is a process carried out by the village government and the rural community to carry out an activity in order to meet their needs with their own abilities; 10) Participation, which is taking an active role in an activity; 11) Equality, i.e. equality in position and role; 12) Empowerment, which is an effort to improve the standard of living and welfare of the rural community through the establishment of policies, programs and activities that are in accordance with the essence of the problems and priorities of the needs of the rural community; 13) Sustainability, which is a process that is carried out in a coordinated, integrated, and continuous manner in planning and implementing rural development programs.

The research results showed that the village fund implements the principles as stated above. All activities related to the village fund, starting from the planning, implementation, supervision, and preservation of the results of development involving all components of the rural community. When planning activities, the village government involved all components of the community to participate in program socialization, the determination of program priorities, to the preparation of the budget plan. In implementing the development of programs funded by the village fund, an Activity Implementation Team was formed, the composition of which consisted of the chairman, secretary, and treasurer. Meanwhile, to guarantee the quality of development, a supervisory team was formed. The supervisory team has the role of supervising the implementing team of activities to realize the agreed development.

Meanwhile, to ensure the sustainability of the activities carried out, an activity conservation team was formed. The activity preservation team has the role of mobilizing rural community participation to maintain the program of development that has been carried out. All the teams formed in the implementation of the village fund come from the local people who are elected democratically, participative, and transparently through community forums in the village. In its implementation, the village fund involves mentoring consultants, starting from the national, provincial, regency, district to the village level.

\section{The Impact of Village Funds Implementation for the Poor}

Based on the results of the study showed that the village fund, which, in its implementation, uses a community approach, its impact is more on the community. Poor households, which are also part of the community where the assistance is provided, are also beneficiaries that directly affect their socioeconomic conditions. The impact of implementing the village fund for the poor can be analyzed based on assistance programs implemented in the village. Based on field data, the programs implemented concerning the implementation of the village fund are as follows: 1) construction of farm roads; 2) bridge construction; 3) drainage construction; 4) cattle fattening; 5) raising cattle; 6) training, i.e., a) baking skills training, b) embroidery skills training, c) automotive training. 
The implementation of the village fund accelerates the development of infrastructure in the village, the benefits of which are felt directly by the village community. Construction of farm roads and bridges is mostly carried out by the village fund program. The construction of farm roads and bridges has opened access to peasants' lands, which has a direct impact on the distribution of agricultural products. By building roads and bridges, it can minimize transportation costs so peasants increasingly income more value from the sale of their agricultural produce. Likewise, drainage development has quite a significant effect in reducing flooding, which usually inundates peasants' agricultural lands. Flooding on peasants' land caused crops that were initially ready to be harvested fail due to flooding. When that happens, peasants have to swallow bitter pills, losses, and being in debt — the benefits of drainage development through the village fund by the rural community.

Based on the results of the study, the village fund not only carried out infrastructure development, but there were also community empowerment activities in the form of cattle fattening, raising cattle, and training. Fattening and cattle programs are provided in groups, where the poor form groups of several people and are given cattle assistance. The results of interviews with groups of recipients of cattle assistance that the village fund program not only assists for cattle to be raised but also facilitates the availability of veterinarians for consultation in case of abnormalities in the cattle they raise. The village fund program also organizes skills training for the community that needs it. Embroidery and embroidery skills training is followed by women, while men prefer automotive training. The villagers who participated in the training were ultimately independent of the business they carried out. This explanation shows that so far, rural communities have benefited from the implementation of village funds so that over time it has created empowered and independent communities. The rural poor are, ultimately, environmentally, socially, and economically empowered. This finding is in line with research conducted by Mustanir and Darmiah (2016) that community participation in the implementation of village funds is in a good category. Likewise, the implementation of policies and village development went well.

\section{CONCLUSION}

The village fund program in implementing poverty eradication applies a community approach. This approach has an impact on improving the welfare of the community, especially poor household communities. The implementation of the village fund applies social principles through approaches to accountability, transparency, participation, democracy, and others. This approach requires the participation of the whole community in the implementation of village funds, from the planning, implementation, supervision, and preservation of development results. Nevertheless, the implementation of the village fund program is inseparable from several problems. These problems found both at the level of local government, advisory assistants, and the community itself.

\section{ACKNOWLEDGMENTS}

The researchers would like to thank the Rector of the State Islamic University of Sultan Amai Gorontalo, Indonesia, and all the leaders who funded this research. The researchers also thanked all the informants who provided information to researchers, both through in-depth interviews and focused group discussions.

\section{REFERENCES}

1. Adam, S., Botutihe, D., \& Obie, M. (2019). Empowering labors in brick factories: Developing institutional organization, training, and access to capital. International Journal of Management, Innovation \& Entrepreneurial Research, 5(2), 11-16. https://doi.org/10.18510/ijmier.2019.522

2. Adam, S., Pattaling, Sumai, S., \& Obie, M. (2019). Inter-stakeholders communication in the implementation of village fund programs: An experience in Gorontalo province, Indonesia. Journal of Management and Sustainability, 9(1), 132-140. https://doi.org/10.5539/jms.v9n1p132

3. Ahluwalia, M. S., Carter, N. G., \& Chenery, H. B. (1979). Growth and poverty in developing countries. Journal of Development Economics, 6(3), 299-341. https://doi.org/10.1016/0304-3878(79)90020-8

4. Anwas, M. O. (2013). Pemberdayaan masyarakat di era global. Alfabeta.

5. Atmojo, M. E., Fridayani, H. D., Kasiwi, A. U., \& Pratama, M. A. (2017). Efektivitas dana desa untuk pengenbangan potensi ekonomi berbasis partisipasi masyarakat di desa Bangunjiwo. Aristo, Sosial Politik Humaniora, 5(1), 126-140.

6. Cahyat. (2004). Bagaimana kemiskinan diukur? Beberapa model perhitungan kemiskinan di Indonesia. Poverty \& Decentralization Project CIFOR: BMZ.

7. Central Bureau of Statistics. (1999). Poor population. BPS

8. Central Bureau of Statistics. (2004). Indonesian statistics. BPS

9. Central Bureau of Statistics. (2018). Profile of the poor in Indonesia. BPS

10. Cox, D. (2004). Outline of presentation on poverty alleviation programs in the Asia Pacific region. Paper presented on the international seminar on curriculum development for social work education in Indonesia, March $2^{\text {nd }}$. College of Social Welfare.

11. Hasniati, Tikson, D. T., \& Syahruddin, M. H. (2017). Peningkatan kesadaran masyarakat dalam pengawasan dana desa di kecamatan Mappakasunggu. Abdimas, 21(2), 119-124.

12. Mardikanto, T., \& Soebiato, P. (2015). Pemberdayaan masyarakat. Alfabeta. 
13. Meutia, I., \& Liliana. (2017). Pengelolaan keuangan dana desa. Jurnal Akuntansi Multiparadigma, 8(2), 336352. https://doi.org/10.18202/jamal.2017.08.7058

14. Ministry of Finance. (2017). Village fund pocketbook: Village fund for people's welfare. Kemenkeu.

15. Mustanir, A., \& Darmiah. (2016). Implementasi kebijakan dana desa dan partisipasi masyarakat dalam pembangunan di desa Teteaji kecamatan Tellu Limpoe kabupaten Sidenreng Rappang. Jurnal Politik Profetik, 04(2), 225-238.

16. National Development Planning Agency. (2006). Technical guidelines for submitting proposed activities funded by foreign loans and grants. Bappenas

17. National Family Planning Coordinating Board. (2013). Report of the 2013 national family planning coordinating board. BKKBN.

18. Nugroho, H. (1995). Kemiskinan, ketimpangan dan pemberdayaan, dalam kemiskinan dan kesenjangan di Indonesia. Aditya Media.

19. Obie, M., Yusuf, I. D. S., \& Sumai, S. (2019). Empowerment of palm sugar peasants at the forest edge of Bogani Nani Wartabone national park, Indonesia: A study of problems, local potentials, and priority ideas towards empowered community. Environment and Natural Resources Research, 9(1), 77-90. https://doi.org/10.5539/enrr.v9n1p77

20. Prawoto, N. (2009). Memahami kemiskinan dan strategi penanggulangannya. Jurnal Ekonomi dan Studi Pembangunan, 9(1), 56-68.

21. Prijono, O. S., \& Pranarka, A. M. W. (1996). Pemberdayaan: Konsep, kebijakan dan implementasi. CSIS.

22. Riyanto \& Junaedi. (2017). Implikasi penggunaan dana desa terhadap ketahanan sosial, ekonomi, dan ekologi desa tertinggal di kabupaten Karanganyar. Jurnal Saintech, 4(2), 1-10.

23. Rostitawati, T., Wahyuddin, N. I., \& Obie, M. (2019). The poverty puddles of the cage fishing community at Limboto lake coast, Indonesia. Journal of Sustainable Development, 12(3), 82-90. https://doi.org/10.5539/jsd.v12n3p82

24. Sajogjo \& Pudjiwati. (2002). Sosiologi pedesaan kumpulan bacaan. Gadjah Mada University Press.

25. Sari, I. M., \& Abdullah, M. F. (2017). Analisis ekonomi kebijakan dana desa terhadap kemiskinan desa di kabupaten Tulungagung. Jurnal Ekonomi Pembangunan, 15(01), 34-49. https://doi.org/10.22219/jep.v15i1.4645

26. Suharto, E. (2010). Membangun masyarakat memberdayakan rakyat kajian strategis pembangunan kesejahteraan sosial dan pekerja sosial. Refika Aditama

27. Sulistyati, M., Herlina, L., \& Nurachma, S. (2011). Dampak proses permberdayaan terhadap keberdayaan peternak domba (influence process of empowerment to empowered sheep farmers). Jurnal Ilmu Ternak, 11(2): 92-97.

28. Suryawati, Ch. (2005). Memahami kemiskinan secara multidimensional. Semarang: Universitas Diponegoro.

29. Suryawati. (2004). Teori ekonomi mikro. UPP. AMP YKPN. Jarnasy.

30. Todaro, M. P., \& Smith, S. C. (2006). Pembangunan ekonomi (edisi kesembilan, jilid I). Erlangga.

31. Wasistiono, S. (1998). Pemberdayaan aparatur daerah. Abdi Praja.

32. World Bank. (1990). Indonesia: Poverty assessment and strategy report. The report, No. 8034-IND, country department III East Asia and Pacific Region.

33. World Bank. (2000). World development report. Attacking poverty. World Bank. 